\author{
KÁDÁR, ZOLTÁN PHD
}

zoltaankadar@gmail.com

assistant professor (University of Szeged Faculty of Arts Department of Sociology)

\title{
History of sociology that focuses more on the background than usual
}



Viktor Karády (2020): Válogatott történelmi szociológiai írások I. A társadalomtudományokról. Replika Alapítvány. 480 p.

DOI 10.14232/belv.2021.4.9

https://doi.org/10.14232/belv.2021.4.9

Cikkre való hivatkozás / How to cite this article: Kádár Zoltán (2021): History of sociology that focuses more on the background than usual. Viktor Karády (2020): Válogatott történelmi szociológiai írások I. A társadalomtudományokról. Replika Alapítvány. 480 p. Belvedere Meridionale vol. 33. no. 4. 119-122. pp

ISSN 1419-0222 (print)

ISSN 2064-5929 (online, pdf)

(Creative Commons) Nevezd meg! - Így add tovább! 4.0 (CC BY-SA 4.0)

(Creative Commons) Attribution-ShareAlike 4.0 International (CC BY-SA 4.0)

www.belvedere-meridionale.hu

In his new book in Hungarian, Viktor Karády presents us eighteen formerly written essays, more than a half of them are translations from French, others from English. These translations were improved, provided with additions that have been appropriate since the majority of the texts written decades ago.

Reading these texts it can be said that - though the topics are mostly known for those who deal with social sciences - the focus the author uses is essentially new. Karády is an insider in French and European sociology as well, thus the point of view he applies in his writings is unique. He is not only a scholar who studied documents about the results the French sociology 
achieved in the second half of the 20th century but a contributor who worked with the greatest figures of this era. As a former member of the research circle of Raymond Aron and Pierre Bourdieu (for a long time as a member of both groups parallelly), he can let the reader experience the atmosphere of this scientific world, beyond the mere information that sociology textbooks can tell. For example, based on the first, autobiographical study we can see that fortune accompanied Karády many times during his scientific career. He was a Hungarian refugee in Paris with poor French knowledge at the start, but after the years he spent in the French academic system - which he described as alienating - obtained a sociology basic license and a demography degree with which he was able to become a well-integrated member in these exclusive scientific circles. But studying social sciences - as he describes it - gave not enough skills to him to do be a proper sociologist: "I can tell that everything I know about the "profession of a sociologist' I learned from Bourdieu. I got this knowledge through a kind of 'osmosis' like reading his writings, my presence at his seminars or sometimes at doctoral thesis defenses, or when I had informal conversations or often phone calls with him, I was able to pick up some crumbs of his scientific remarks". ${ }^{1}$ This is reminiscent of what Albert Szent-Györgyi told in an interview about the role of university training when he visited Hungary in October of 1973. As the Noble prize winner told the interviewer 'at first it is a kind of an intellectual hunger what is needed, this is the important part that remains in the rest of man's life. Because when I finish my university training I forget everything and what remains there is this intellectual hunger, and then I follow to nurture my mind with knowledge, with steadiness...'2

This is what worked in the case of Karády's too, that is wanting to know more than that a formal university training can offer, and this is why we can find extra content in each of his essays in this volume. The importance of gaining knowledge from practice can be seen from the story in which he describes the difficulties he needed to go through when he was the editor of the three-volume Marcel Mauss oeuvre series around 1966-67. Reading this autobiographical story one can see how much knowledge can derive from such an undertaking when a social scientist's task is editing scientific materials and analyzing documents.

All the writings in the book that deal with early French sociology and French cultural or academic life can be regarded as a gold mine for those who are interested in this epoch, but it is much more useful for those who teach sociology as university teachers. Numerous studies deal with the foundation of French sociology and the breakthrough of the Durkheimians. The reader gets a perfect picture of the contemporary French higher educational system and all those factors that could help or hinder the institutionalization of the new science, sociology. There is a very interesting fact that helped a lot for sociology: the Durkheimians were originally philosophers, so they were inside the system and turned philosophy towards sociological questions. As acknowledged contributors of the field of human sciences, Durkheimians did not meet maximal resistance from the side of the academic system. With this advantage, the first theoreticians of sociology could slowly expand the frames of the social sciences to make room for their new discipline. The four writings in the book that deal with the 'foundation syndrome in French sociology' show how scientifically based sociology has grown itself from 'mysticism' to an accepted and blossoming

KARÁDY 2020. 21.

2 Interview with Albert Szent-Györgyi, 8-19 ${ }^{\text {th }}$ of october 1973. 
discipline. And we can also see how Durkheimians helped other disciplines - such as ethnology - join the academic system.

Karádi also provides in-depth analyzes of the fact that, although ethnology wanted to establish itself on a strictly scientific basis from the beginning, it was only about half a century later that this discipline could take its roots in the French academic environment. The insight Karádi provides through these studies clearly shows the general resistance of the traditional way of the late nineteenth century French academic world against everything that was new or not 'French' by its origin. The long neglect of ethnology is because French scientific circles were not willing to accept it as a normative science, so this discipline - unlike the German, English, or American models - could not develop and grow. Ethnology as a new science was not able to present the kind of historicity that could have made it worthy to become a part of the higher culture and the education system. Ethnology had nothing to present that would have made its themes and objects worthy of national celebration. There were no great historical events or figures among its topics that French scientific circles could have admired. That is why ethnology could not become a normative science. Moreover, since ethnology concentrated on different foreign peoples, tribes, etc., the imprints of French ethnocentrism could not reflect through it, nor could the greatness of the French nation be cheered at the sight of the results of this discipline. The 'archivist's rigor' of the French academic system, therefore, did not find a catch on it that would have made it part of the university curriculum. In addition, ethnography used an illegal way of acquiring knowledge, i.e. its researcher did not use to visit the library or the archives - the realm of classical canonized knowledge - but traveled to visit distant cultures and foreign countries. All of this was completely incomparable with the typical figure of a French scientist who obtains information from classical knowledge. The scientist who is seeking recognition in the French scientific life is therefore not working on trying new methods, or leaving the urban area, but using the source of the classical knowledge as deeply as possible, then undertakes a job as a teacher at a university or at a high school to achieve the desired academic position over a long period of years, Karády points out. Thus ethnology, as a new scientific territory that uses the observation of everyday life and also fieldwork, had no chance in its early stage of development to gain admission to the French academic environment around the end of the nineteenth century. For this reason, French ethnography had to build its framework and publicity outside the academic sphere, with the involvement of various entrepreneurs, travelers, colonial officials as contributing persons. In France, the process of becoming a formal knowledge for Ethnology could therefore only take place decades later. Apart from this Ethnology could more or less become a part of the scientific world by publishing its results as a co-science of physical anthropology. Because of this linkage, Ethnology had to accept evolutionism as a guiding principle, and the foreign cultures needed to be regarded through this optic. Thus, Ethnology remained a kind of descriptive empiricism without well-developed standards until the reorganization of the university research system by the French state after the first World War. Ethnology, as a social science that examines real social facts needed to wait until the Durkheimians' breakthrough to find a decent place in the academic system. Durkheim and his colleagues (Mauss, Hubert, Fauconnet, Davy, Hertz, and Richard) often used the data extracted by ethnology to support their theoretical works, and as a result, Ethnology was gradually introduced into the University's acknowledged disciplines. The University of Paris finally founded its Ethnological Institute in 1925, with a great delay though. 
Karády devotes several studies in this volume to the interpretation of some Hungarian-related aspects of the history of sociology from different perspectives. He makes his claims with strong empirical data, such as mentions in newspapers and magazines, and when it is possible he uses prosopography. He examines, for example the use of foreign literature related to sociology during the Austrian-Hungarian Monarchy, the Horthy era, and the Kádár regime as well as the times after the regime change of 1989-1990. As he claims 'During the strong German-centricity as the member of the Monarchy, post-feudal Hungary can therefore rightly be considered as a German cultural colony' ${ }^{3}$, but even before the end of the first world war, there is a growing demand for the use of French and English scientific sources as well. We can see from the data collected by Kárady that in the Hungarian sociological journals of the first decades of the twentieth century a significant part of the sources of publications are in foreign languages. It is German and French in the 1910s and 1920s, then English appears strongly from the 1930s, and by 1944 the latter precedes the French sources. The period until 1944 was - according to Karády - a more or less free scientific development process of sociology even in the semi-feudal eras of the Monarchy and the Horthy-system, but the studies also show off the times ruled by the communist party Karády leads us through these decades as well, showing that apart from a few (more or less) free years and democratic development after 1945, the circumstances of academic research how greatly changed after 1948. All educational institutions, like book publishing, the press, and all cultural or intellectual activities were nationalized by the communists. The social sciences were strictly limited to its Marxist-Leninist versions and sociology soon after 1948 was banned for decades. All the university curriculums were transformed based on bolshevik patterns, but we can of course read about the improving situation regarding sociology from 1970, the weakening communist influence, and the times after 1989 when the Hungarian academic life needed to adapt to the western patterns again, and the communist type higher education structure needed major transformations to be able to connect to the western academic models.

All in all, Karády's new book is a very important one that offers deeper insight into the history of sociology and the social sciences as well. It can be (and hopefully the future volumes will be too) regarded a compulsory background material, especially for teaching.

\section{REFERENCES}

KARÁDY VIKTOR(2020): Válogatott történelmi szociológiai írások I. Atársadalomtudományokról. Replika Alapítvány. 